\title{
UNDERSTANDING SUSTAINABILITY, CORPORATE SOCIAL RESPONSIBILITY AND RESPONSIBLE TOURISM IN LITERATURE VS PRACTICE
}

\author{
Love Odion IDAHOSA* \\ School of Tourism and Hospitality, University of Johannesburg, \\ Auckland Park, Johannesburg, e-mail: loveoi@uj.ac.za
}

\begin{abstract}
Citation: Idahosa L.O. (2019). UNDERSTANDING ENVIRONMENTAL SUSTAINABILITY, CORPORATE SOCIAL RESPONSIBILITY AND RESPONSIBLE TOURISM IN LITERATURE VS PRACTICE. GeoJournal of Tourism and Geosites, 26(3), 956-973. https://doi.org/10.30892/gtg.26322-410
\end{abstract}

\begin{abstract}
This paper provides evidence of the gaps in literature vs practice with regard to three sustainability and tourism related concepts: environmental sustainability, corporate social responsibility, and responsible tourism. A conceptual framework on the linkage between these concepts, as described in the literature, is developed and juxtaposed with a framework developed from content analysis of 30 interview transcripts where tourism accommodation industry stakeholders discuss their understanding of these concepts. Results reveal significant areas of overlap between theory and practice with outliers unique to the geographical and industry context. This highlights the importance of taking the local context into consideration in academic research and enquiry relating to industry and practice. These findings are relevant for academics and policymakers who aim to develop policy solutions to address sustainability challenges and improve CSR and responsible tourism uptake in their respective local contexts.
\end{abstract}

Keywords: Environmental sustainability, Corporate Social Responsibility, Responsible Tourism, Accommodation, Literature vs Practice.

\section{INTRODUCTION}

The conversation on the need for environmental sustainability in tourism is extensive and rich and has even given birth to the concept of 'responsible tourism' which is lauded as the correct way to ensure that tourism is not only profitable but also sustainable (Cape Town Declaration, 2002; Musavengane, 2019). This approach has been adopted, not only by academics but also, by multinational organisations such as the UNWTO who operate in the tourism support and regulation space at the international level (World Tourism Organisation (UNWTO), 2016). At the industry and practice level, the adoption of sustainable tourism practices has become a trend, with tourism operators even carving out niches based on an 'environmental sustainability

\footnotetext{
* Corresponding author
} 
compliance' branding, evident in the emergence of a new tourism type branded 'ecotourism' (Andersson \& James, 2018). Many of these operators have learned to advertise their products as being sustainable and while in some cases, these practices are genuine, many establishments that advertise the sustainable tourism brand have, at best, basic sustainability compliance, with the majority of them having very little compliance evidence to back up their claim (Andersson \& James, 2018; Chen et al., 2019; Parguel et al., 2011; Ramus \& Montiel, 2005). Similarly, to stay trendy with the sustainability fad, environmental sustainability has been fused with Corporate Social Responsibility (CSR), especially at the firm level, with many organisations branding their CSR activities as environmental sustainability, and vice versa.

In many cases, the reason for this has been attributed to a lack of honesty by businesses, encouraged by the capitalist paradigm of profitability at whatever cost (Chen et al., 2019; Ramus \& Montiel, 2005). However, in this paper, a different reason is proposed and investigated, especially in realisation of the fact that understanding of technical concepts such as sustainability and corporate responsibility is context-specific (Morelli, 2011). The reason is framed around the following question: do these businesses understand what it means to be sustainable? This question is pertinent, especially in the Global South where the dynamics of civil society education is not only poor (i.e. with high illiteracy rates) (Cooper \& Ozdil, 1992; Kimbu \& Tichaawa, 2018; Matten \& Moon, 2008; Tichaawa, 2017), but also seldom incorporates the need for environmental consciousness and sustainability in its curriculum (Leal Filho et al., 2019; Nagendra, 2018). Although many tourism programs at the higher education level now incorporate sustainability in their curriculum, this would not translate to improved understanding in tourism markets in the Global South as the majority of tourism operators do not have formal tourism training (Bakker, 2019; Fatima et al., 2019).

Adopting South Africa as a Global South case study, this paper investigates the extent to which tourism operators in the accommodation industry understand the concept of environmental sustainability and how it relates to tourism. Primarily, the extent to which conversations on sustainability, CSR and responsible tourism in academic discourses have any bearing on industry understanding and practice is investigated to assess if academic conversations are relevant and understood at the industry level. To do this, a conceptual framework is developed which links academic literature's conceptualisation of three terms - environmental sustainability, corporate social responsibility, and responsible tourism - to industry conceptualisations. These concepts have gained significant attention in the literature and Figures 1 and 2 show the trend in total publication of the three concepts in the last two decades as retrieved from Web of Science (Clarivate, 2019) and Google Scholar (Google, 2019). The choice of these concepts is further driven by the significant overlap between them, especially in tourism discourse and literature. The data in Figure 1 and 2 were sourced by searching for each term within the two databases and compiling the total result outputs over the period 2000 to 2019. The choice of Google Scholar and Web of Science was driven by their reputation as reliable scholarly databases (Falagaset al., 2008). Figures 1 and 2 show that CSR and environmental sustainability have followed a very similar trend, reaching their peak around the year 2013, according to Google Scholar, although the CSR literature dominated the sustainability literature by up to $200 \%$ in most years. The responsible tourism literature has not been as dominant, maintaining a relatively constant publication rate over time, only picking up momentum in the last decade.

In this study, the literature interpretation of each of these three concepts is explored and synthesised to develop a conceptual framework. Field data from tourism 
operators' understanding of the three concepts in South Africa is then analysed in line with the conceptual framework developed to identify existing gaps and areas of overlap between the academic understanding and industry's understanding. Based on the gaps and areas of overlap identified between academia and industry, recommendations are made for closing existing gaps identified to ensure that on the side of academia, future research is based on the appropriate premise (i.e. correct understanding of field conceptualisation of concepts) to ensure the continued relevance of academia to real-life contexts.

Literature Trend - Total Publications 2000 to 2019 Web of Science

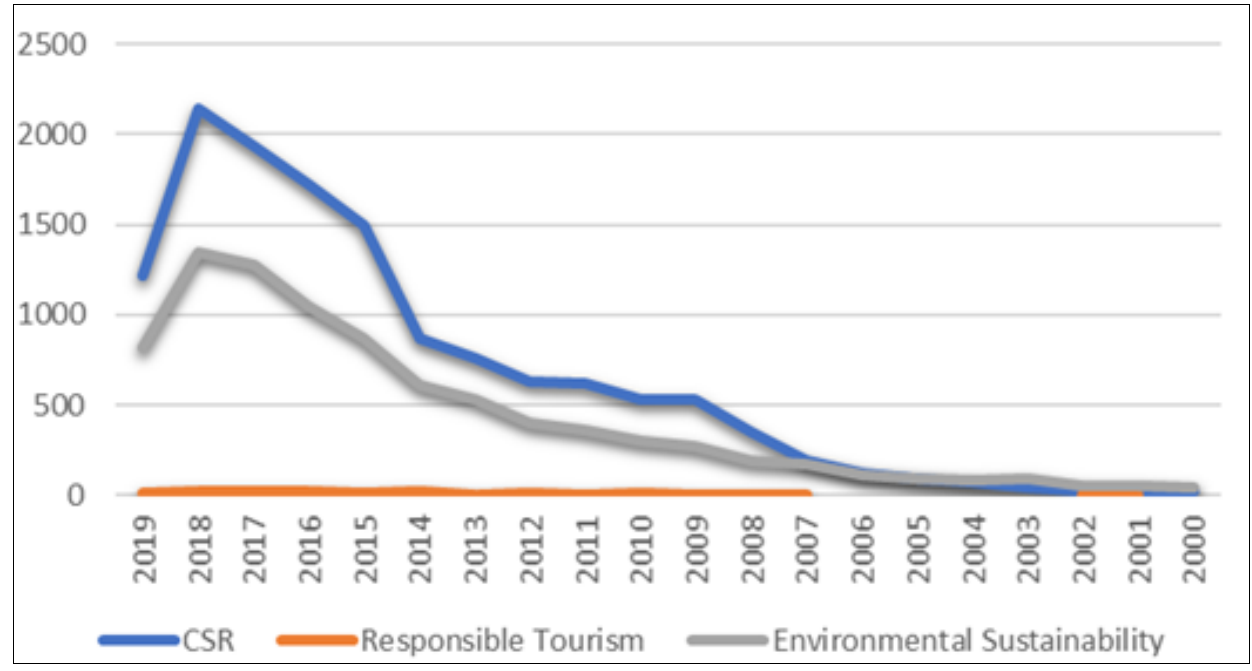

Figure 1. Web of Science Publication Trend on CSR, Responsible

Tourism and Environmental Sustainability (Source: Clarivate, 2019)

Literature Trend - Total Publications 2000 to 2019 Google Scholar

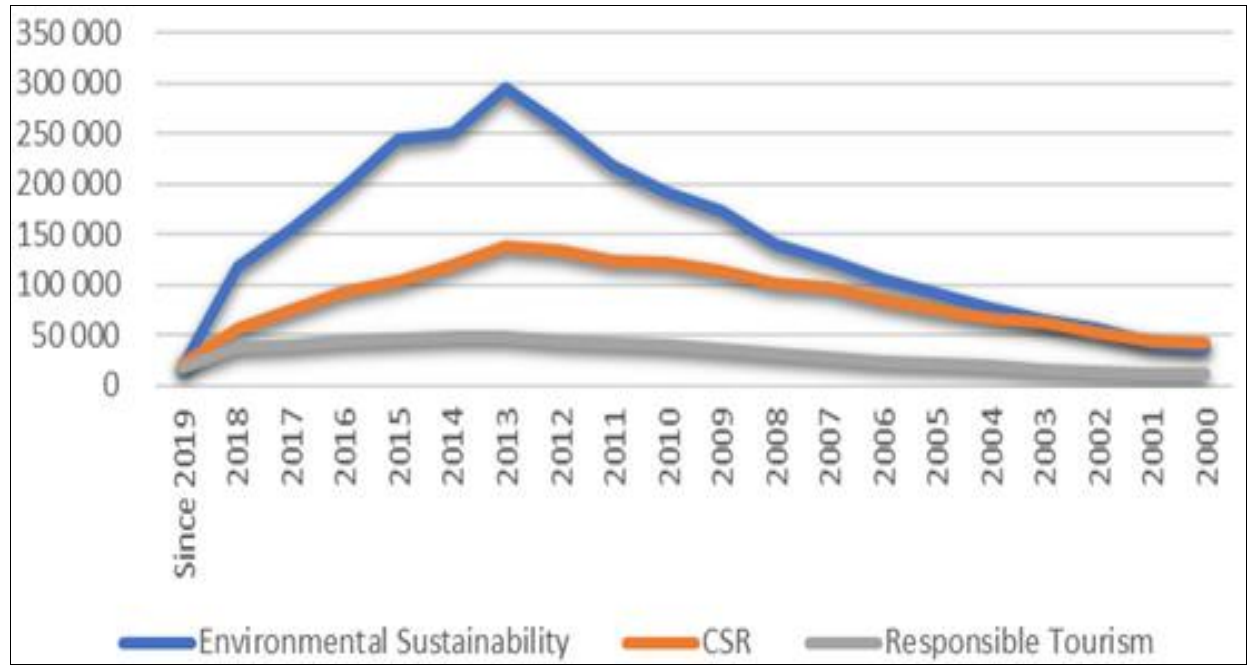

Figure 2. Google Scholar Publication Trend on CSR, Responsible Tourism and Environmental Sustainability (Source: Google 2019) 
The study also recommends that when research into industry practices and activities are made, especially when evaluating industry compliance, evaluating the extent of understanding of the concepts in the field in each context is an important starting point if correct conclusions are to be drawn from data analysis. This is all the more important given that the extent of understanding will differ with each context, especially in varying Global South settings (Matten \& Moon, 2008; Duarte et al., 2010).

\section{Environmental Sustainability}

In the literature, the concept of environmental sustainability is often used interchangeably with 'sustainable development' and 'sustainability' more loosely (Leuenberger, 2007; Morelli, 2011). In all cases, reference is made to consideration of the environment/ecosystem in which humans dwell. Central to the discourse of environmental sustainability is the concept of climate change. In fact, in many academic studies, it forms the basis for approaching the sustainability debate as the biggest environmental threat facing humanity and the planet (Coleman et al., 2017; Nolet, 2015; Williams \& Schaefer, 2013). Climate change is primarily concerned with the health of the planet and ensuring that its capacity to heal itself is not compromised to the detriment of humanity. At the core is ensuring the resilience of both the planet and the people and species inhabiting it (Leuenberger, 2007; United Nations, 2019).

Beyond academia, climate change is also the focus of sustainability, with governmental policies, and even civil education, addressing the sustainability issue from this perspective (Coleman et al., 2017; Leuenberger, 2007; Williams \& Schaefer, 2013). Given that even at the most basic level of introduction to sustainability - schools, climate change is chosen at the preferred example for easing students into the sustainability concept (Nolet, 2015; Coleman et al., 2017), it is plausible to assume that general understanding of environmental sustainability by civil society, as well as industry practitioners, would incorporate some elements of climate change. This climate change approach to environmental sustainability can be argued to embody an understanding of the concept to mean resilience building.

Similarly, a discussion on environmental sustainability is incomplete without reference to sustainable development (Leuenberger, 2007; Morelli, 2011). With climate change identified as one of the most threatening issues of our time, with daunting implications for human survival, sustainable development, defined as "development that meets the needs of the present without compromising the ability of the future generations to meet their own needs", has taken centre stage and emphasises the need for changes in human behaviour to address the alarming rate of the degradation and depletion of the planet (World Commission on Environment and Development (WCED), 1987). This take emphasises the view of environmental sustainability as ensuring the continued survival of mankind in its habitat - an idea that can be referred to as preservation.

A general consensus in the move towards sustainability is that ensuring the desired intergenerational equity would most certainly require a change in lifestyle and/or behaviour to incorporate an interconnected view of relating to the planet. This would require a balanced approach that involves not just changes in consumption behaviour (Peattie \& Peattie, 2009; Barr et al., 2011), but more deliberative and involved leadership transformation that engages civil society in sustainable development planning. In fact, Leuenberger (2007: 372) argues that "traditional, expert-based models of change may not address the impending problems of environment quickly enough and that a wider, deliberative, and transforming type of change must be adopted by leaders." This transformative type of change would warrant not only a modification of citizens' lifestyle, but also of corporate lifestyle. 


\section{CSR}

The call for corporates to change the way business is done, especially in relation to society, pre-dates the environmental movement, and is more generally known as CSR. The literature on CSR is vast and far more extensive than that of (environmental) sustainability. At its inception, it was simply referred to as 'social responsibility' (Drucker, 1984; Kolk, 2016) with mentions of the concept as far back at the 1920 in the monographs of John Maurice Clark (1926). CSR quickly grew in popularity in the literature due to its departure from the Adam Smith school of thought in the proposition that business had obligations to society beyond the economic motive of profitability. Where Adam Smith had argued that the market, in pursuing its objective of profit maximisation, will result in society's needs being met, CSR propagators, in recognition of the failure of Smith's assumption and the widening inequality fostered by large firms pursuing their profit motives, argued that firms needed to go beyond their legal business mandates and engage in activities to improve the society (Duarte et al., 2010).

CSR activities also gained momentum with the realisation that for firms to pursue their profitability objective, they needed to ensure that their immediate operating environment is conducive for business to run smoothly. Firms, hence, had to go 'beyond profits' to secure their social capital if business was to be a success in the long run (Kolk, 2016; Mohr et al., 2001; Spence, 2016). As the centre of the discourse, the extent of 'beyond profits' has been the focus of the literature to date. In the earlier literature, this economic objective of profit-making to satisfy investors and business partners was emphasised as a key component of business's responsibility but this emphasis grew quieter over time (Duarte et al., 2010). The focus was turned to satisfying employees and society as equally relevant stakeholders in the firm's framework. The emphasis on employees referred mostly to how they were treated, focusing on issues such as decent work environments, fair wages, employee welfare, work-life balance, upskilling and capacity development, and other workplace issues (Barnett, 2019; Camilleri, 2016; Carroll, 1999; Matten \& Moon, 2008; Musavengane, 2019). The society-focused approach emphasised operating within society's legal, moral and ethical framework, and going beyond this to 'giving to society' through philanthropism, volunteerism, socially responsible investment, and other forms of discretionary corporate contributions to society (Camilleri, 2016; Freeman \& Hasnaoui, 2011; Matten \& Moon, 2008). In essence, the focus of CSR was on business-society relations. This is reflected in the most cited CSR model in the literature in the 1980, '9os and early 2000 s by Carroll $(1979,1999)$ where 'four pillars' of the firm's responsibility to society were itemised in a pyramid model.

These pillars were: (1) the economic responsibility which emphasised Adam Smiths' idea of making profit by producing goods and services of value for society; (2) the legal responsibility of operating within the legal framework of society; (3) the ethical responsibility to stick to society's morals and norms; (4) and the voluntary/discretionary responsibility of contributing to the development of society. This approach highlights the fact that the decision on what is 'responsible' according to CSR and what activities can be included as a corporate's responsibility is entirely at the discretion of the corporate/firm, although this is increasingly influenced by pressure from academics and civil society.

Where in modern literature, it can be argued that it is impossible to divorce sustainability from the CSR discourse, this was not always the case. The four pillars model and other earlier models were silent on the environment. It is only in recent times, especially with the increased propagation of climate change concerns and need for environmental sustainability, has the concept of the environment been integrated into the definition and understanding of CSR (Duarte et al., 2010). The award for the most popular 
model of CSR in contemporary literature which incorporates environmental concerns can arguably be attributed to the 'triple-bottom-line' model developed by John Elkington (1998). This model follows the trajectory of its predecessors in that it emphasises people (social responsibilities) ahead of profits (economic activities) and is unique in its incorporation of the planet (environmental responsibility) as a stand-alone objective / responsibility of business. The CSR emphasis of this model is consistent with the tenets of sustainable development where economic prosperity is encouraged but with an emphasis on human and environmental preservation (Chuang \& Huang, 2018; European Commission, 2001).

\section{Responsible Tourism.}

Responsible tourism can be argued to be CSR-customised for the tourism industry. It draws its roots from the sustainable tourism movement embedded in the global call for sustainable development (Saarinen, 2018). Following the definition of sustainable development by the Brundtland Commission as "development that meets the needs of the present without compromising the ability of future generations to meet their own needs" (World Commission on Environment and Development (WCED), 1987: 41), the World Tourism Organisation (WTO) specified that "Sustainable tourism development meets the needs of the present tourists and host regions while protecting and enhancing the opportunity for the future. It is envisaged as leading to management of all resources in such a way that economic, social, and aesthetic needs can be fulfilled while maintaining cultural integrity, essential ecological processes, biological diversity and life support systems" (World Tourism Organization, 1998).

Given that communities and the natural environment constitutes the tourism industry's base of operation and main industry product, the emergence of responsible tourism can be said to be a natural product of the increased climate change concerns and corresponding call for sustainability, combined with the growth in CSR uptake in the private sector driven by both academia and civil society (Burrai et al., 2019; Caruana et al., 2014). The origin of the concept of responsible tourism can be traced to Krippendorf (1987) but was formalised at the international level at the 'Responsible Tourism in Destinations' conference in South Africa, an event which preceded the 2002 World Summit on Sustainable Development and culminated in the Cape Town Declaration (Burrai et al., 2019; Fennell, 2008; van der Merwe \& Wöcke, 2007). The Cape Town Declaration defines Responsible tourism as "tourism which:

- minimises negative economic, environmental and social impacts;

- generates greater economic benefits for local people and enhances the wellbeing of host communities;

- improves working conditions and access to the industry;

- involves local people in decisions that affect their lives and life chances;

- makes positive contributions to the conservation of natural and cultural heritage embracing diversity;

- provides more enjoyable experiences for tourists through more meaningful connections with local people, and a greater understanding of local cultural, social and environmental issues;

- provides access for physically challenged people;

- is culturally sensitive, encourages respect between tourists and hosts, and builds local pride and confidence" (2002: 2).

From this definition, the responsible tourism concept espouses the concerns of sustainable tourism but takes this further by emphasising morals and ethics as they relate to tourism's impact on local communities and surroundings, hence aligning with the more 
general CSR term, defined by the World Travel and Tourism Council (WTTC) as "the means of adopting open and transparent business practices that are based on ethical values" (as cited by Frey \& George, 2010: 623). These values are further elaborated in the ten principles of the UN Global Compact (2005 a, b). This responsible tourism definition, however, emphasises a stakeholder-community approach in defining what constitutes the best business practice. Klein (2011) categorises the focus of the responsible tourism definition into three broad groups: (1) the environmental impact of tourism; (2) fair and equitable distribution of the economic benefits of tourism to the host communities; and (3) mitigating the negative socio-cultural and heritage impact of tourism. Responsible tourism, hence, lays emphasis on incorporating local/host communities in the decisionmaking process, improving access to employment opportunities for local community members, contributing to responsible governance, abnegating corruption, reducing economic leakages, increasing inclusion for women and the disabled, ensuring fair labour standards, and ensuring that resources (natural, ecological, cultural, and heritage) are sustainably managed (Booyens, 2010; Burrai et al., 2019; Caruana et al., 2014; Cooper \& Ozdil, 1992; Fennell, 2008; Idahosa, 2018; Klein, 2011).

Responsible tourism and CSR can be said to be similar in that they are both discretionary in the definition of what activities fall within the purview of the firm, although responsible tourism stretches the firm-centred decision making to a more inclusive stakeholder-centred approach. As such, when considering responsible tourism, the focus is not on whether or not the corporate adopts certain best practices, but on the impact of its activities on the host population and environment (Fennell, 2008; Klein, 2011; Saarinen, 2018). In the tourism literature, the two terms (CSR and responsible tourism) are, however, often used interchangeably (Caruana et al., 2014; Frey \& George, 2010). Although the term is often associated with terms such as ethical tourism, pro-poor tourism, and ecotourism (van der Merwe \& Wöcke, 2007; Pro Poor Tourism (PPT), 2002; Yu et al., 2019), it is important to highlight that while these forms of tourism constitute tourism niches/products, responsible tourism is not a product but a 'way of doing tourism' (Cape Town Declaration, 2002; Department of Environmental Affairs and Tourism, 2002; Booyens, 2010).

\section{The Nexus Between Environmental Sustainability, CSR, and \\ Responsible Tourism}

While the preceding discussion already highlights that a close relationship exists between environmental sustainability, CSR and responsible tourism, for the purpose of this study, the discussed literature is synthesised using the content analysis method to develop a conceptual framework that establishes the areas of overlap in the three concepts. In this synthesis, at least ten studies relevant to each literature concept were consulted to identify the keywords and terminologies associated with each concept. Studies in the fringes of the literature were also consulted to identify new words or terms that might emerge. For this study, only words which occur in at least five studies were included and only selected studies where the words occur are referenced in this article. Finally, the key terms/words associated with each concept in the literature were identified and then mapped based on common occurrence to create the word map in Figure 3. Words are categorised based on their association to the main concept(s) and distinguished by colours. Words in blue, red, and green boxes are unique to each individual concept. The words in blue boxes are unique to responsible tourism and include host/local community and environment, government support, pro-poor tourism, visitor safety and security, ethical tourism, cultural sensibilities, ecotourism, and sustainable tourism. This highlights a focus on tourism niches associated with sustainability and business-society relations. 
Understanding Sustainability, Corporate Social Responsibility and Responsible Tourism in Literature vs Practice

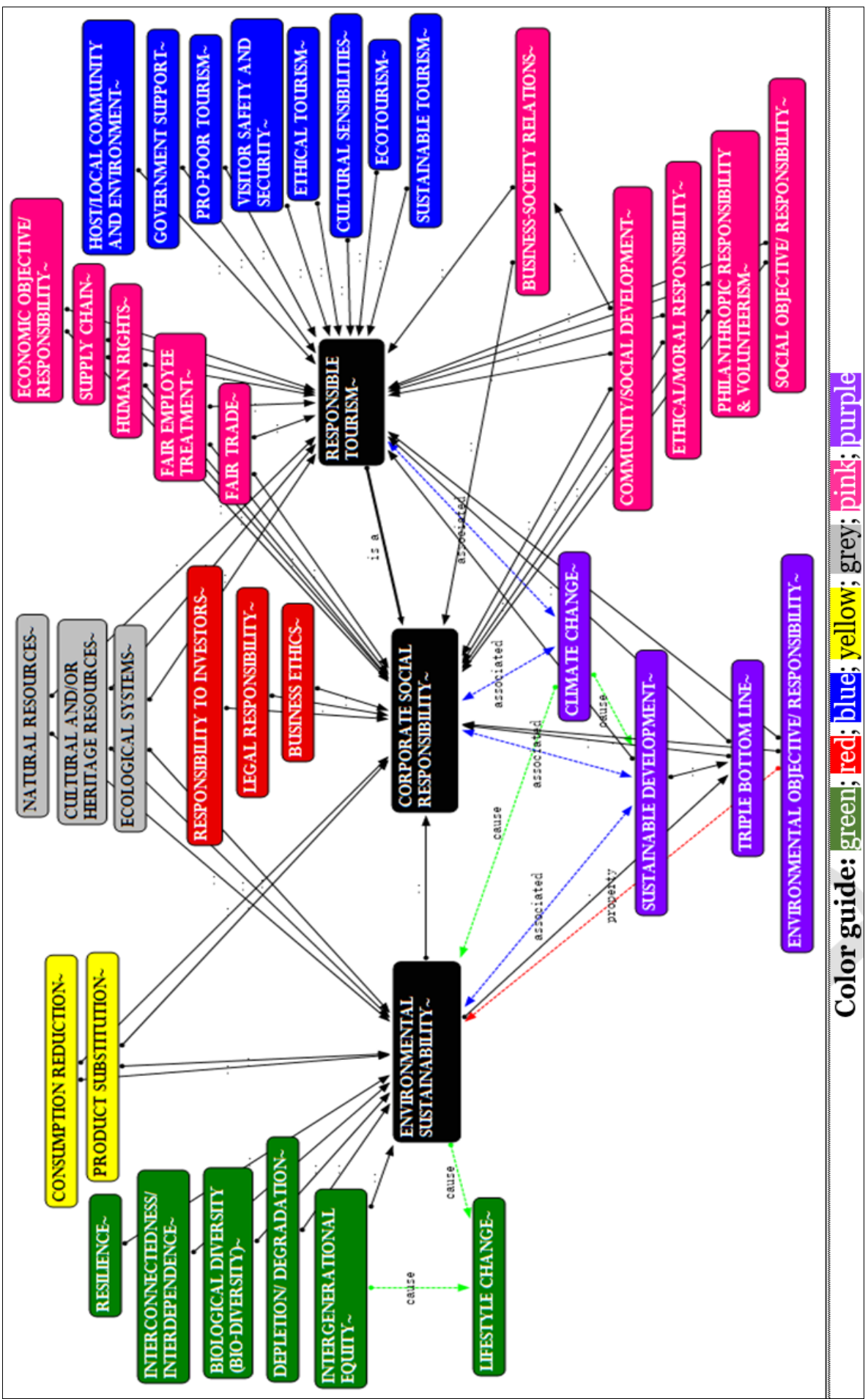

Figure 3. The Nexus between ES, CSR, and Responsible Tourism 
The existence of these business niches in tourism, crafted around the global demands for sustainability and more accountable business-society relations, is a telling feature of the industry's dependence on communities, the environment, and society for success (Hassan, 2000; Mathew \& Sreejesh, 2017). Similarly, words in red boxes are unique to $C S R$. They include business ethics, legal responsibility, and responsibility to investors, and highlight a primarily internal focus that has to do with the firm's framework of operations in ensuring its continued survival. Words in green boxes are unique to environmental sustainability and reveal a focus on preserving the natural environment, not just for itself, but as a prerequisite for human preservation. Words such as biological diversity, depletion/degradation, and resilience reflect the environmental preservation focus, while intergenerational equity reflects the human preservation focus.

Interconnectedness/interdependence highlights the relationship between the environmental and human focus while lifestyle change indicates that the dynamics of this relationship is such that the human side needs a major overhaul of its pattern of existence. Stakeholder engagement is a critical part of responsible tourism in the reviewed literature and these stakeholders include employees, government, supply chain, tourists/visitors, and investors. As expected, the three concepts of interest also share common words/terms identifiable by their colours. The words in the purple boxes are words common to all three concepts in the literature: climate change, sustainable development, triple-bottom-line, and environmental objective/responsibility. The need for 'environmental responsibility' necessitated by climate change is the common denominator in sustainable development and the triple-bottom-line concepts, and hence, ties all three concepts in this study together.

The words in the two sets of pink boxes are those which are common to CSR and responsible tourism in the literature: business-society relations, community/social development, ethical/moral responsibility, philanthropic responsibility and volunteerism, social objective/responsibility, economic objective/responsibility, 'supply chain' management, human rights, and fair employee treatment, and fair trade. These terminologies, especially when juxtaposed with the individual focus of each concept, emphasises the 'stakeholder management' view both CSR and responsible tourism share. Words in grey boxes are common to environmental sustainability and CSR and include consumption reduction and product substitution. These accentuate an internal focus on resource management habits in the firms. Words in orange boxes are common to environmental sustainability and responsible tourism and include natural resources, cultural and/or heritage resources, and ecological systems, and highlight the delicate nature of resources which sustain the human population and provide the source and environment for many economic activities. The identified areas of uniqueness and overlap across the main concepts under consideration in this study, as presented in Figure 3, form the basis for comparing literature understanding/perspective to industry understanding of the concepts.

\section{MATERIALS AND METHODS The study area}

The chosen study area for collecting the relevant data consisted of two major urban municipalities in the Cape - Cape Town and Cape Winelands - with a significant concentration of tourism products. Cape Town is a popular tourist destination in South Africa, attracting about 2 million visitors per year, and has won numerous awards, including the UNESCO 2017 'City of Design' award and the 'Travel+Leisure' 2018 World's Best Awards (Cape Town Tourism, 2017). The Cape Winelands, well known for its wine routes, lies about 25 nautical miles from Cape Town and is a generous beneficiary of the tourism traffic that Cape Town receives. 


\section{Data Collection and Analysis}

Data for this study was collected using semi-structured interviews. The interview guide was developed from an in-depth literature review, benchmarked with similar questionnaires in the literature and validated with management-level industry stakeholders. The sample frame for the study was developed using South Africa's Tourism Grading Council's website to identify areas where accommodation establishments were concentrated within the survey area. The targeted convenience sampling technique was then adopted to identify participants based on relevance to the study (i.e. tourism accommodation establishments), distance, availability, and willingness to participate (Mays \& Pope, 2000). A snowballing approach was also adopted to identify and include establishments that were not registered with the grading council (Burton, 2000). This ensured that the final sample was inclusive, incorporating a wide range of accommodation types regardless of star grading, type, or size. Interviews were conducted with 30 establishments, after which saturation was reached. These interviews lasted between 25 minutes to 65 minutes and took place in the winter of 2015 (between March and September). All interviews were transcribed, coded manually using Friese's (2014) Noticing, Collecting, and Tagging (NCT) framework, and then re-coded in Atlas.ti for analysis using the Qualitative Content Analysis approach. The choice of the content analysis approach was motivated by its flexibility in allowing texts to be synthesised into related categories based on meaning and concept. This makes it ideal for qualitative data analysis where the research questions and concepts are already pre-defined (Elo \& Kyngäs, 2008; Schreier, 2012). Codes developed a priori from the literature were incorporated with the transcribed text and analysed to develop a framework that highlights the main focus areas for each of the three concepts of interest in the industry.

\section{The sample}

The target population for this study consisted of people at the management level within tourism accommodation establishments in the study sample. These included owners, sustainability directors, administrators, operations managers, and general managers within each firm, depending on who was available for interviews. The decision to focus on individuals at the management level was driven by the fact that their positions require that they be involved in the decision making and day-to-day running of the establishments, including engaging with external stakeholders, and taking part in training and development opportunities when they present themselves (see Idahosa (2018); Tang, et al. (2014) for similar approaches). A summary of the sample characteristics is provided in Table 1 . The sample collected reveals that the ownership structure of the accommodation industry in the study area is dominated by individual/family-owned businesses and partnerships. This is a result of the monopolistically competitive market structure where firms are free to enter and exit the market as they like with no restrictions, as well as the economic viability of tourism in the region - being one of the largest tourism destinations on the continent. This is also reflected in the establishment types, sizes and ratings, with smaller establishments (backpackers, BnBs and guest houses) dominating the scene (53\%), supplying at most 50 rooms (67\%) and mostly graded three-star and below (57\%).

The participant pool reveals the flexibility of the market structure where more than half of the respondents hold both technical and administrative positions (e.g. the general manager also doubles as a maintenance manager). The sample is male-dominated - a pattern only observed at the managerial level as the majority of employees in the industry are female, with most of them (57\%) working within the industry for at least a decade. Despite the gender bias, the sample demographics demonstrate that the participants hold authoritative positions to provide information on the subject of interest. 
Table 1. Sample Characteristics (Data source: Fieldwork, 2015)

\begin{tabular}{|c|c|c|c|}
\hline \multicolumn{2}{|l|}{ (2) } & $\%(\mathrm{~N}=30)$ & Cumulative \% \\
\hline Establishment characteristics & & & \\
\hline \multirow{3}{*}{ Ownership structure } & Single owner/family & 53.3 & \\
\hline & Partnership & 13.3 & 66.6 \\
\hline & Business group/ Board of Directors & 33.4 & 100 \\
\hline \multirow{6}{*}{$\begin{array}{l}\text { Duration in business/business } \\
\text { age }\end{array}$} & o to 5 years & 16.7 & \\
\hline & 6 to 10 years & 20.0 & 36.7 \\
\hline & 11 to 20 years & 23.3 & 60 \\
\hline & 21 to 30 years & 23.3 & 83.3 \\
\hline & More than 30 years & $13 \cdot 3$ & 96.6 \\
\hline & Unknown & $3 \cdot 3$ & 100 \\
\hline \multirow{3}{*}{$\begin{array}{l}\text { Number of rooms in } \\
\text { establishment }\end{array}$} & o to 10 rooms & 26.7 & \\
\hline & 11 to 50 rooms & 40 & 66.7 \\
\hline & More than 50 rooms & 33.3 & 100 \\
\hline \multirow{5}{*}{ Star grading } & No Star & 20.0 & \\
\hline & Two Star & 3.3 & 23.3 \\
\hline & Three Star & $33 \cdot 3$ & 56.6 \\
\hline & Four Star & 40.0 & 96.6 \\
\hline & Five Star & 3.3 & 100 \\
\hline \multirow{4}{*}{ Accommodation type } & Backpacker & 13.3 & \\
\hline & $\mathrm{BnB}$ & $13 \cdot 3$ & 26.6 \\
\hline & Guest house & 26.7 & 53.3 \\
\hline & Hotel & 46.7 & 100 \\
\hline \multicolumn{4}{|l|}{ Participant's characteristics } \\
\hline \multirow{3}{*}{ Participant's designation } & Administrative & 40.0 & \\
\hline & Technical & 6.7 & 46.7 \\
\hline & Both & 53.3 & 100 \\
\hline \multirow{4}{*}{$\begin{array}{l}\text { Participant's duration in the } \\
\text { hospitality industry }\end{array}$} & o to 5 years & 33.3 & \\
\hline & 6 to 10 years & 10.0 & 43.3 \\
\hline & 11 to 20 years & 36.7 & 80 \\
\hline & More than 20 years & 20.0 & 100 \\
\hline \multirow{2}{*}{ Participant's Gender } & Female & 46.7 & \\
\hline & Male & 53.3 & 100 \\
\hline
\end{tabular}

\section{RESULTS DISCUSSIONS}

To facilitate analysis, separate individual frameworks, derived from content analysis of participants' interview transcripts, are presented for each of the three main concepts of interest in this study (see Figures 4, 5, and 6). Each framework presents words that capture the industry's understanding of each concept and is then compared to the conceptual framework presented in Figure 3 to identify areas of similarities and differences. In Figure 4 to 6, the main concept under consideration is located in the middle of the diagram with arrows pointing to, or away, from it. Words in the box with the red dotted outline are those which, in the literature, are associated with the concept in focus but do not occur in the analysis of participants' interview transcripts. Words outside the red box, with arrows pointing towards or away from the main concept under consideration, represent those that occur both in the literature and the data transcripts. Finally, during the data analysis, additional words common to some of the main concepts were identified beyond those found in the literature. These words, while found in the literature to be un-associated with the main concept under consideration in Figures 4, 5, and 6 respectively, come up as linked to each respective concept under 
consideration in the data analysis. They are identifiable in each of Figure 4, 5, and 6, as those with no arrow links to the main concept addressed by each figure.

\section{Environmental Sustainability - Industry Context}

Figure 4 shows that the literature's understanding of environmental sustainability as relating to climate change, environmental responsibility, sustainable development, consumption reduction, product substitution, depletion/degradation, interconnectedness, and need for intergenerational equity, resulting in lifestyle change, all resonate with the study's sample. However, more formal concepts such as the triple-bottom-line, sustainable development, biological diversity, resilience, ecological systems, and culture/heritage resources did not come up amongst the description of environmental sustainability by the accommodation operators in the sample. Beyond the literature's description of the term, respondents also referred to environmental sustainability as relating to terms more often associated with CSR and responsible tourism in the literature such as fair trade, the economic responsibility of creating jobs, community/social development, supply chain activities, and more generally, the way the businesses relate to their communities and the society at large. The climate change understanding is palpable amongst respondents with repeated reference to the need for 'greening' of organisational practices, and for minimising carbon footprints.

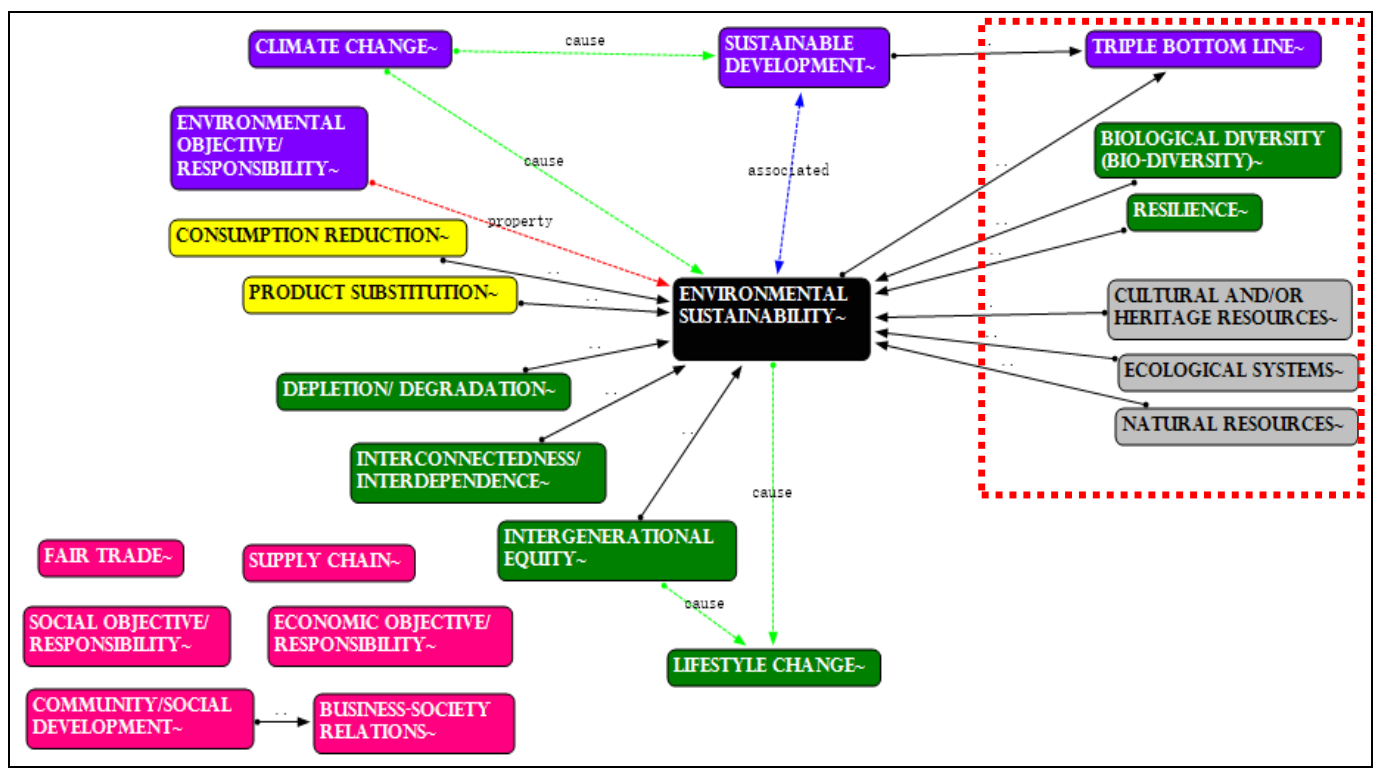

Figure 4. Environmental Sustainability Conceptualisation in the Industry (Source: Fieldwork, 2015)

\section{CSR - Industry Context}

A key observation from Figure 5 is that the majority of operators in this space do not consider the 'economic responsibility/profits' as CSR.

The inclusion of 'economic responsibility' as a common term between the industry and the literature is a result of only one respondent's reference to 'creating jobs' as a CSR. Most respondents link CSR to consumption reduction and product substitution, community/social responsibility, and environmental responsibility. The omission of the economic side of things in the respondent's understanding of CSR indicates that the theoretical models in the literature such as Elkington's (1998) triple- 
bottom-line and Carroll's $(1979,1999)$ pyramid model of business obligations do not reflect the understanding in this study's sample. Similarly, the link to climate change which comes up in the literature does not occur in the sample, neither do sustainable development, ethical/moral responsibility, responsibility to investors, or fair trade.

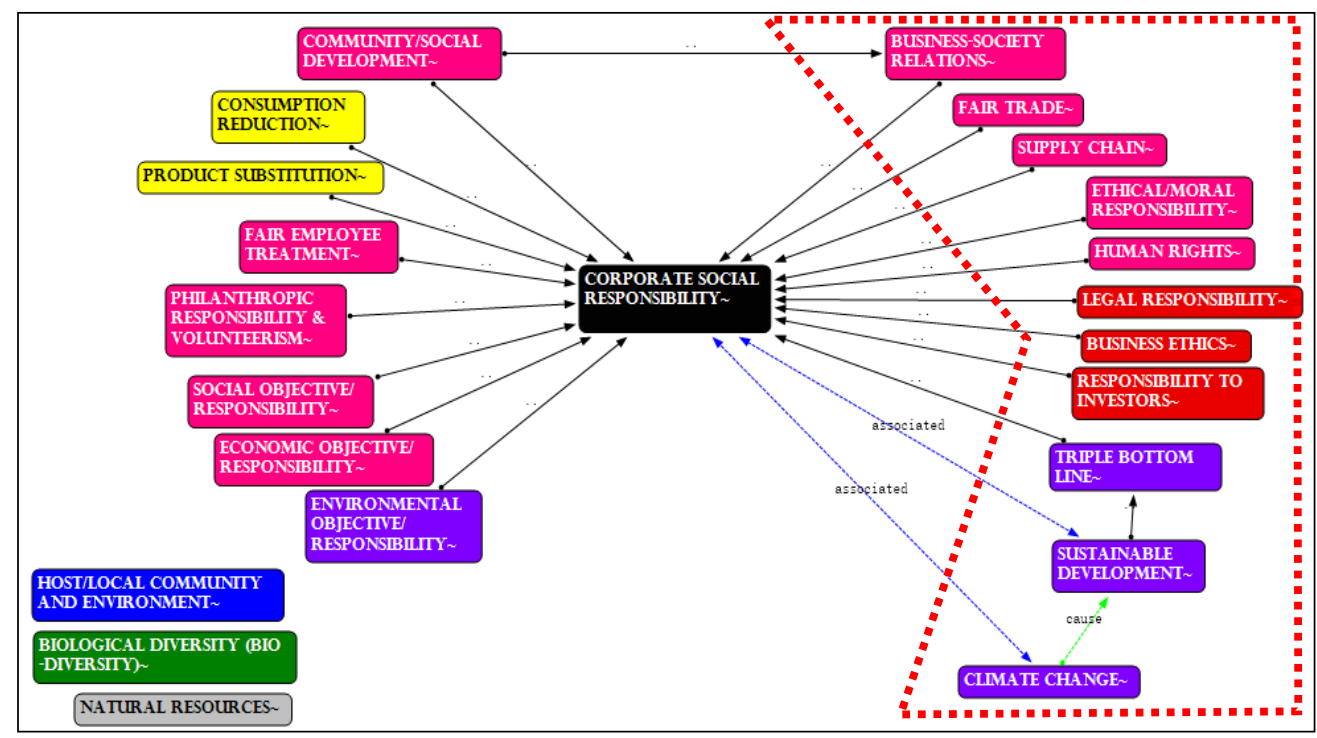

Figure 5. CSR Conceptualisation in the Industry (Source: Fieldwork, 2015)

Respondents' understanding of CSR centres around their responsibility and interactions with their communities, their employees, and the environment. This includes philanthropic donations to the disadvantaged and charities; educating guests on the need to be environmentally conscious and to respect the local ecosystem; being conscious of their resource consumption habits by reducing consumption and substituting resources with environmentally sustainable alternatives where possible; and employee-related responsibilities which include employing locally, training their employees and giving them opportunities to develop themselves. Respondents expressed the understanding that in employing and training members of the local community, they were also contributing to the development of the community. The analysis also shows that in addition to understanding CSR as including environmental responsibility, the study respondents also linked the concept to their responsibility to their host communities/environment - an idea that occurs more pronouncedly in the responsible tourism literature than in the CSR literature. This supports the argument put forward in this study that Responsible Tourism is CSR-customised to the tourism industry, emphasising the firm's relationship to the host/local community and environment. Similarly, the environmental sustainability emphasis on biological diversity is linked to CSR, suggesting that CSR in this location is strongly associated with the environmental component.

\section{Responsible Tourism - Industry Context}

The results of responsible tourism understanding are presented in Figure 6. An interesting finding is the fact that all the terms synonymous with responsible tourism in the literature (i.e. ethical tourism, ecotourism, pro-poor tourism, sustainable tourism) do not come up in this study sample. Similar to the CSR finding, more theoretical concepts like the triple-bottom-line, sustainable development and ecological systems, 
which permeate the literature, do not come up in respondents' description of their understanding of responsible tourism. Similarly, the literature's focus on culture and heritage, human rights and ethical behaviour, and other external stakeholder (e.g. government and supply chain) engagement and responsibilities, are missing from the study respondents' understanding of responsible tourism. The only external stakeholders alluded to in the description of what responsible tourism is, were communities and tourists, with emphasis for tourists being on ensuring their safety and security. Responses are, however, very strong on the issue of community engagement and development, philanthropy and volunteerism, fair employee treatment, fair trade, climate change, and environmental responsibility. One respondent also referred to financial sustainability as a component of responsible tourism, alluding to the economic responsibility of the firm as identified in the literature. Also, beyond the literature's description of the term, respondents in this study emphasised resource management (i.e. consumption reduction and product substitution) as key aspects of responsible tourism in order to address issues of depletion and degradation.

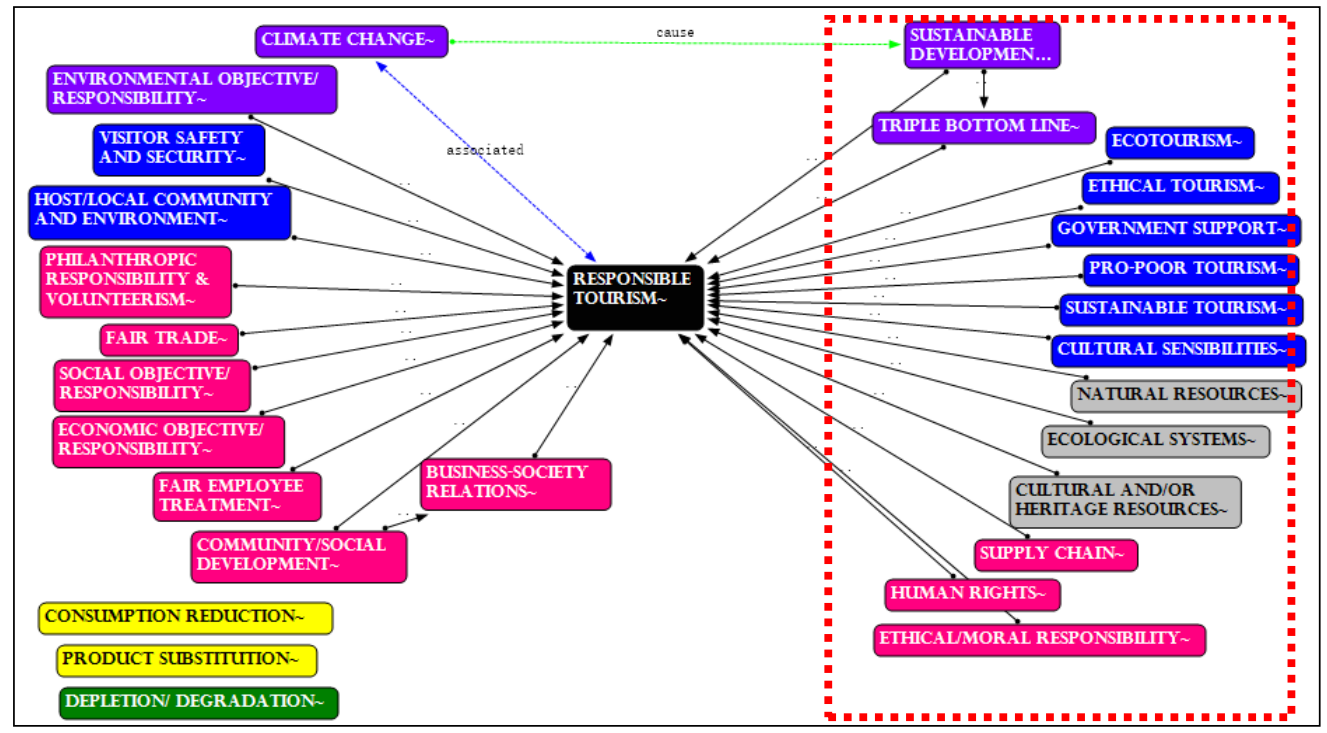

Figure 6. Responsible Tourism Conceptualisation in the Industry (Source: Fieldwork, 2015)

\section{Discussion}

These results indicate that while there are significant areas of overlap between the literature and the local accommodation industry context in the Cape in the understanding of environmental sustainability, CSR, and responsible tourism, there are also areas of dissonance, which highlight the importance of factoring in the local contextual understanding of academic concepts when carrying out academic research into practices in the industry. For example, where the triple-bottom-line and sustainable development concepts are a conspicuous component of CSR and responsible tourism in the literature, these terms do not occur in the data collected for the study. The fact that the sample does not link these terms to CSR and responsible tourism is further highlighted by the limited occurrence of the 'economic responsibility' of the firm as a CSR item in the data. This can be explained by the characteristic of the local geography where the industry is monopolistically competitive, such that formal education in business management - 
where the exposure to these CSR models and concepts are taught - is not required to run an accommodation establishment, especially for locally owned establishments which form the bulk of the population. The results also show that in the study sample, respondents do not distinguish uniquely between sustainability, CSR and responsible tourism, as is done in the literature. As opposed to the literature where environmental sustainability is typically focused on the planet/physical environment, respondents in this study considered both their social/community and economic responsibilities as part of environmental sustainability, indicating a fusion of the concept of sustainability with CSR and responsible tourism. This can be argued to be indicative of the way knowledge is disseminated in the industry in this geographical location where discussions on responsibility in tourism overlap and are not finely separated into economic, social or environmental responsibility, as is done in the literature.

Furthermore, consistent with the literature, respondents had a strong 'climate change' approach to understanding sustainability with an emphasis on 'carbon footprints' and 'greening'. This is explainable by the extreme weather conditions experienced by residents in South Africa in the last decade, which have triggered popular civil society conversations, and have been explained as resulting from global warming due to climate change (Wright et al., 2015; Alfreds 2018; Writer, 2019). This perspective triggers an individual consciousness to modify behaviour which is demonstrated in the popularity of 'consumption reduction' and 'product substitution' as key terms associated with sustainability and business responsibility. This is consistent with the findings of Idahosa (2018), as it reveals that the operators in the accommodation industry understand issues of environmental sustainability and responsible tourism as relating primarily to how resources are managed in terms of consumption reduction and product substitution. This is contrary to the literature where product usage is not a strong emphasis in the responsible tourism discourse. This might be because the data for this study was collected within the same period as Idahosa's (2018) study during which South Africa was going through severe energy and water shortages (Cohen \& Burkhardt, 2015; Fioramonti, 2015; Idahosa, 2018), and demonstrates the way in which the socioeconomic, environmental, and even political occurrences in a local context can influence stakeholder's understanding of academic and global concepts. The finding that all the terms synonymous with responsible tourism in the literature (i.e. ethical tourism, ecotourism, pro-poor tourism, sustainable tourism) do not come up the current study can be said to support the argument put forward by Cooper and Ozdil (1992) who argue that these tourism niches are more the preserve of developed economies in the Global North. Consistent with their finding for Portugal which had then only just launched its tourism product, responsible tourism in South Africa, particularly in the accommodation industry in the Cape, is more focused on the host communities and environments (Cooper \& Ozdil, 1992; Fatima et al., 2019). This finding can also be attributed to the fact that the focus of this study is on accommodation establishments only. Given that niches such as ecotourism and pro-poor tourism are more the preserve of the tour operators industry, it is plausible that studies investigating this segment of the industry will yield different findings.

\section{CONCLUSION}

This study explores the extent to which the academic literature reflects the local industry's understanding of three key concepts in the tourism accommodation industry: environmental sustainability, corporate social responsibility, and responsible tourism. Following a synthesis of the literature for key words used to explain and/or describe each of these concepts, the study finds that these concepts largely overlap, and are, in some 
cases, embedded within each other. For example, the environmental responsibility aspect of environmental sustainability is a common theme across both CSR and responsible tourism. While this environmental aspect has not always been a prominent aspect of the CSR discourse, it has seen a proliferation in its incorporation in CSR since the proliferation of the climate change debate in the last two decades. Consequently, climate change occurs as a common thread across all three concepts, as does sustainable development and the triple-bottom-line. The literature synthesis also indicates that responsible tourism is a form of CSR, customised for the tourism industry. This is presumably a result of the strong dependence of the industry on the environment and on local communities, which in most cases constitute the industry's product sources and even final products and is evidenced by the development of tourism niches and ideas such as ecotourism and pro-poor tourism which brand themselves as unique based on a CSR approach - a phenomenon which is rarely observed in other industries.

A comparison of the synthesised literature to a content-analysed framework of 30 interviews from managers and operators in the accommodation industry in the Cape region of South Africa, indicates significant areas of overlap between industry and the literature in the understanding of the three concepts, as well as differences that reflect the uniqueness of the local geography. The focus on climate change and resourcemanagement in the understanding of sustainability in the data is attributed to the shifts in weather patterns in the study area which has dominated civil society conversations. Similarly, the data is silent on technical terminologies such as triple-bottom-line and sustainable development which is indicative of the local economic (Global South) environment which does not require formal management qualifications to run accommodation establishments. The accommodation specialisation of the study's participants is also evident in their understanding of responsible tourism as terms such as ecotourism and pro-poor tourism, which are associated with responsible tourism in the literature, do not come up in the data, arguably because they are more the preserve of the tour operators sub-industry. This study demonstrates that while the literature, to a large extent, captures the pulse of this local geography on the concepts of environmental sustainability, CSR, and responsible tourism, idiosyncrasies unique to the environmental and socio-economic characteristics of the region, as well the specific industry focus (i.e. accommodation), have a significant bearing on how these concepts are understood by industry practitioners. This not only calls for caution in the way technical academic terms are interpreted and utilised during field research, especially in Global South contexts, but also for the need to ascertain how these concepts are understood in the interpretation of research data and results.

\section{REFERENCES}

Alfreds, D. (2018). Here are the SA cities facing the biggest threat from climate change. [Online], Available at: https://www.news24.com/Green/News/here-are-the-sa-cities-facing-the-biggest-threat-from-climatechange-20180619 [Accessed 29 August 2019].

Andersson, I. \& James, L. (2018). Altruism or entrepreneurialism? The co-evolution of green place branding and policy tourism in Växjö, Sweden. Urban Studies, 55(15):3437-3453.

Bakker, M. (2019). A conceptual framework for identifying the binding constraints to tourism-driven inclusive growth. Tourism Planning \& Development, 16(5):575-590.

Barnett, M.L. (2019). The business case for corporate social responsibility. Business \& Society, 58(1):167-190.

Barr, S., Gilg, A. \& Shaw, G. (2011). Helping people make better choices: Exploring the behaviour change agenda for environmental sustainability. Applied Geography, 31(2):712-720.

Booyens, I. (2010). Rethinking township tourism: Towards responsible tourism development in South African townships. Development Southern Africa, 27(2):273-287. 
Burrai, E., Buda, D.-M. \& Stanford, D. (2019). Rethinking the ideology of responsible tourism. Journal of Sustainable Tourism, 27(7):992-1007.

Burton, D. (2000). Sampling strategies in survey research. In D. Burton (Ed.), Research Training for Social Scientists (pp. 307-319). London: SAGE Publications Ltd.

Camilleri, M.A. (2016). Responsible tourism that creates shared value among stakeholders. Tourism Planning \& Development, 13(2):219-235.

Carroll, A.B. (1979). A three-dimensional conceptual model of corporate performance. Academy of Management Review, 4:497-505.

Carroll, A.B. (1999). Corporate social responsibility: Evolution of a definitional construct. Business \& Society, 38(3):268-295.

Caruana, R., Glozer, S., Crane, A. \& Mccabe, S. 2014. Tourists' accounts of responsible tourism. Annals of Tourism Research, 46:115-129.

Chen, H., Bernard, S. \& Rahman, I. (2019). Greenwashing in hotels: A structural model of trust and behavioral intentions. Journal of Cleaner Production, 206:326-335.

Chuang, S.-P. \& Huang, S.-J. (2018). The effect of environmental corporate social responsibility on environmental performance and business competitiveness: The mediation of green information technology capital. Journal of Business Ethics, 150(4):991-1009.

Clark, J.M. (1926). Social control of business. Chicago: University of Chicago Press.

Cohen, M. \& Burkhardt, P. (2015). Six ways SA is tackling its electricity crisis. [Online], Available: https://www.fin24.com/Economy/Eskom/Six-ways-SA-is-tackling-its-electricity-crisis-20150908 [Accessed 29 August 2019].

Coleman, K., Murdoch, J., Rayback, S., Seidl, A. \& Wallin, K. (2017). Students' understanding of sustainability and climate change across linked service-learning courses. Journal of Geoscience Education, 65(2):158-167.

Cooper, C.P. \& Ozdil, I. (1992). From mass to "responsible" tourism: the Turkish experience. Tourism Management, 13(4):377-386.

Drucker, P.F. (1984). The new meaning of corporate social responsibility. California Management Review, XXVI(2):53-63.

Duarte, A.P., Mouro, C. \& Das Neves, J.G. (2010). Corporate social responsibility: Mapping its social meaning. Management Research, 8(2):101-122.

Elkington, J. (1998). Cannibals with forks : the triple-bottom-line of 21st century business. Capstone. Oxford, United Kingdom.

Elo, S. \& Kyngäs, H. (2008). The qualitative content analysis process. Journal of Advanced Nursing, 62(1):107-15.

Falagas, M.E., Pitsouni, E.I., Malietzis, G.A. \& Pappas, G. (2008). Comparison of PubMed, Scopus, Web of Science, and Google Scholar: strengths and weaknesses. The FASEB Journal, 22(2):338-342.

Fatima, J.K., Ghandforoush, P., Khan, M. \& Mascio, R. Di. (2019). Mobile learning adoption for tourism education in a developing country. Current Issues in Tourism, 22(4):420-427.

Fennell, D.A. (2008). Responsible tourism: A Kierkegaardian interpretation. Tourism Recreation Research, 33(1):3-12.

Fioramonti, L. (2015). Water shortages about to put load-shedding in the dark. [Online], Available: https://governanceinnovation.org/water-shortages-about-to-put-load-shedding-in-the-dark-businessday-05-05-2015/ [Accessed 29 August 2019].

Freeman, I. \& Hasnaoui, A. (2011). The meaning of corporate social responsibility: The vision of four nations. Journal of Business Ethics, 100:419-443.

Frey, N. \& George, R. (2010). Responsible tourism management: The missing link between business owners' attitudes and behaviour in the Cape Town tourism industry. Tourism Management, 31(5):621-628.

Friese, S. (2014). Qualitative data analysis with ATLAS.ti. 2nd ed. Los Angeles, Washington DC: SAGE.

Hassan, S.S. (2000). Determinants of market competitiveness in an environmentally sustainable tourism industry. Journal of Travel Research, 38(3):239-245.

Idahosa, L.O. (2018). Environmental sustainability and tourism accommodation in South Africa : The managers' perspective. EuroEconomica, 37(1):259-275.

Kimbu, A. \& Tichaawa, T.M. (2018). Sustainable development goals and socio-economic development through tourism in Central Africa: Myth or reality? GeoJournal of Tourism and Geosites, XI(23):780-796.

Klein, R.A. (2011). Responsible cruise tourism: Issues of cruise tourism and sustainability. Journal of Hospitality and Tourism Management, 18(1):107-116.

Kolk, A. (2016). The social responsibility of international business: From ethics and the environment to CSR and sustainable development. Journal of World Business, 51(1):23-34.

Krippendorf, J. (1987). Ecological approach to tourism marketing. Tourism Management, 8(2):174-176.

Leal Filho, W., Vargas, V.R., Salvia, A.L., Brandli, L.L., Pallant, E., Klavins, M., Ray, S., Moggi, S., et al. (2019). The role of higher education institutions in sustainability initiatives at the local level. Journal of Cleaner Production, 233:1004-1015.

Leuenberger, D.Z. (2007). Introduction - signs of the times: Environmental sustainability, citizens, leadership, and social justice. Administrative Theory and Praxis, 29(3):370-374.

Mathew, P. V. \& Sreejesh, S. (2017). Impact of responsible tourism on destination sustainability and quality of life of community in tourism destinations. Journal of Hospitality and Tourism Management, 31:83-89 
Understanding Sustainability, Corporate Social Responsibility and Responsible Tourism in Literature vs Practice

Matten, D. \& Moon, J. (2008). "Implicit" and "explicit" CSR: A conceptual framework for a comparative understanding of corporate social responsibility. Academy of Management Review, 33(2):404-424.

Mays, N. \& Pope, C. (2000). Qualitative research in health care. Assessing quality in qualitative research. BMJ (Clinical research ed.), 320(7226):50-2.

Mohr, L.A., Webb, D.J. \& Harris, K.E. (2001). Do consumers expect companies to be socially responsible? The impact of corporate social responsibility on buying behavior. The Journal of Consumer Affairs, 35(I):45-72.

Morelli, J. (2011). Environmental sustainability: A definition for environmental professionals. Journal of Environmental Sustainability, 1(1):1-10.

Musavengane, R. (2019). Small hotels and responsible tourism practice: Hoteliers' perspectives. Journal of Cleaner Production, 220:786-799.

Nagendra, H. (2018). The global south is rich in sustainability lessons that students deserve to hear. Nature. 557(7706):485-488.

Nolet, V. (2015). Educating for sustainability. Routledge. London, United Kingdom.

Parguel, B., Benoît-Moreau, F. \& Larceneux, F. (2011). How sustainability ratings might deter 'greenwashing': A closer look at ethical corporate communication. Journal of Business Ethics, 102(1):15-28.

Peattie, K. \& Peattie, S. (2009). Social marketing: A pathway to consumption reduction? Journal of Business Research.,62:260-268.

Ramus, C.A. \& Montiel, I. (2005). When are corporate environmental policies a form of greenwashing? Business \& Society, 44(4):377-414.

Saarinen, J. (2018). Beyond growth thinking: the need to revisit sustainable development in tourism. Tourism Geographies, 20(2):337-340.

Schreier, M. (2012). Qualitative content analysis in practice. Los Angeles: SAGE Publications Ltd.

Spence, L.J. (2016). Small business social responsibility. Business \& Society, 55(1):23-55.

Tang, Y.H., Amran, A. \& Goh, Y.N. (2014). Environmental management practices of hotels in Malaysia: stakeholder perspective. International Journal of Tourism Research, 16(6):586-595.

Tichaawa, T.M. (2017). Business tourism in Africa: The case of Cameroon. Tourism Review International, 21(2):181-192.

van der Merwe, M. \& Wöcke, A. (2007). An investigation into responsible tourism practices in the South African hotel industry. South African Journal of Business Management, 38(2):1-15.

Williams, S. \& Schaefer, A. (2013). Small and medium-sized enterprises and sustainability: Managers' values and engagement with environmental and climate change issues. Business Strategy and the Environment, 22(3):173-186.

Wright, C.Y., Engelbrecht, F. \& Sweijd, N. (2015). The three culprits behind South Africa's weird weather patterns. [Online], Available: http://theconversation.com/the-three-culprits-behind-south-africasweird-weather-patterns-50613 [Accessed 29 August 2019].

Writer, S. (2019). New report shows alarming weather changes in South Africa. [Online], Available: https://businesstech.co.za/news/lifestyle/315344/new-report-shows-alarming-weather-changes-insouth-africa/ [Accessed 29 August 2019].

Yu, L., Wang, G. \& Marcouiller, D.W. (2019). A scientometric review of pro-poor tourism research: Visualization and analysis. Tourism Management Perspectives, 30:75-88.

*** Cape Town Declaration. (2002). Responsible Tourism in Cape Town. Cape Town.

*** Cape Town Tourism. (2017). Annual report: Looking back and looking rorward. Cape Town.

*** Clarivate. (2019). Web of Science. [Online], Available: http://molecular-cancer.biomedcentral.com/articles/ 10.1186/1476-4598-12-41.

*** Department of Environmental Affairs and Tourism. (2002). Responsible Tourism Manual for South Africa. South Africa: Department for Environmental Affairs and Tourism.

*** European Commission. (2001). Green paper: Promoting a European framework for corporate social Responsibility. Brussels.

*** Global Compact. (2005a). What is the UN global compact? [Online], Available: https://www. unglobalcompact.org/what-is-gc [Accessed 24 August 2019].

*** Global Compact. (2005b). The ten principles of the UN global compact. [Online], Available: https://www.unglobalcompact.org/what-is-gc/mission/principles [Accessed 24 August 2019].

*** Google. (2019). Google Scholar. [Online], Available: https://scholar.google.com/ [Accessed 29 August 2019].

*** Pro-Poor Tourism (PPT). (2002). What is pro-poor tourism? [Online], Available: http://propoortourism. org.uk/pro-poor-tourism [Accessed 24 August 2019].

*** United Nations. (2019). Why does climate change matter? [Online], Available: https://www.unenvironment .org/explore-topics/climate-change/why-does-climate-change-matter [Accessed 19 August 2019].

*** World Commission on Environment and Development (WCED). (1987). Brundtland report: Our common future.

*** World Tourism Organisation (UNWTO). (2016). The tourism sector and the sustainable development goals: Responsible tourism, a global commitment. Spain.

*** World Tourism Organization. (1998). Sustainable tourism development: Guide for local authorities on developing sustainable tourism. World Tourism Organization.

Submitted:

28.06.2019
Revised:

14.10.2019
Accepted and published online 16.10.2019 